\title{
THE NORTHERNMOST RECORD OF THE LOGGERHEAD SEA TURTLE, CARETTA CARETTA (TESTUDINES, CHELONIIDAE), IN THE BLACK SEA, WITH THE REVIEW OF THE SPECIES OCCURRENCE IN THE REGION
}

\author{
O. Zinenko' ${ }^{1}$ K. A. Vishnyakova ${ }^{2}$, L. Stoyanov ${ }^{3}$, P. E. Gol'din ${ }^{2,4, *}$ \\ ${ }^{1}$ V. N. Karazin Kharkiv National University, 4 Svobody Sq., Kharkiv, 61022 Ukraine \\ ${ }^{2}$ Ukrainian Scientific Centre of Ecology of the Sea, Frantsuzsky Blvrd., 89, Odesa, 65000 Ukraine \\ ${ }^{3}$ National Scientific Center "Institute of Experimental and Clinical Veterinary Medicine" \\ Pushkinska st., 83, Kharkiv, 61083 Ukraine \\ ${ }^{4}$ Schmalhausen Institute of Zoology, NAS of Ukraine \\ vul. B. Khmelnytskoho, 15, Kyiv, 01030 Ukraine \\ ${ }^{\star}$ Corresponding author \\ E-mail: pavelgoldin412@gmail.com \\ O. Zinenko (https://orcid.org/0000-0001-5228-9940) \\ K. A. Vishnyakova (https://orcid.org/0000-0002-6455-6601) \\ P. E. Gol'din (https://orcid.org/0000-0001-6118-1384)
}

\begin{abstract}
The Northernmost Record of the Loggerhead Sea Turtle, Caretta caretta (Testudines, Cheloniidae), in the Black Sea with the Review of the Species Occurrence in the Region. Zinenko, O, Vishnyakova, K. A., Stoyanov, L., Gol'din, P. E. - A rare live record of the loggerhead sea turtle Caretta caretta (Linnaeus, 1758) is reported from the Dzharylhach Gulf in the north-western Black Sea. This is the first record from Ukrainian waters since 1962 and the northernmost record of the species in the Black Sea. The loggerhead sea turtles of the east Mediterranean origin are increasingly often seen in the Marmara and the Black Seas during the latest decade, which is an evidence for potential northward expansion of this species range, at least partly due to climate changes. The review of published observation during the 20th and 21 st centuries is provided.

Key words: sea turtles, Caretta caretta, Black Sea, Ukraine, range expansion.
\end{abstract}




\section{Introduction}

The Black Sea, unlike the Mediterranean region as a whole, is lacking sea turtles in its modern fauna. Historically, only the south-western Black Sea was a habitat for turtles in the 16th century (Georgiev, 1979; Nankinov, 1998). Their subsequent disappearance can be explained either by exploitation by humans (Georgiev, 1979; Nankinov, 1998) or climate cooling. During the 19-20th centuries, two turtle species, the loggerhead sea turtle Caretta caretta (Linnaeus, 1758) and the green turtle Chelonia mydas (Linnaeus, 1758) were extremely rarely sighted across the Black Sea, also only in its south-western part (Nankinov, 1998) but a single record of the loggerhead near Kerch (Ukraine) in September 1962 (Taranenko, 1963) (fig. 1). Among the records, the loggerhead dominated and this corresponds with the present-day higher abundance of this species in the Marmara Sea (Tonay \& Oruç, 2016; Özdilek et al., 2018). Meanwhile, a growing number of loggerhead observations were reported from the Black Sea during the latest decade (Pestov \& Kletnoy, 2012; Tonay\& Oruç, 2016; Anonymous, 2019).

Here we report a new record of the loggerhead sea turtle in the Ukrainian waters of the north-western Black Sea, in the Dzharylhach (Jarılgac) Gulf. To our knowledge, this is the northernmost record of this species in the Black Sea (and the entire Mediterranean region) and the second historical record for Ukraine after 1962. We also briefly discuss the present-day trend of sea turtle sightings in the Black Sea region.

\section{Material and methods}

The loggerhead sea turtle was live bycaught by a local fishermen in the Dzharylhach (Jarilgac) Gulf, north to the Dzharylhach (Jarilgac) Island (approximate coordinates $46^{\circ} 03^{\prime} \mathrm{N}, 33^{\circ} 03^{\prime} \mathrm{E}$ ), released to the sea on September 25, 2020, and encountered again on October 4. It was weighted and photographed, and video records were taken in Skadovsk before the release. Body size and measurements were tentatively estimated from photo and video records.

\section{Results}

The specimen was identified as the loggerhead sea turtle upon having five costal scutes, the nuchal scute contacting costal scutes, two pairs of prefrontal scales, and an interprefrontal scale between them (Musick, 2003). The turtle had at least $60 \mathrm{~cm}$ carapace length

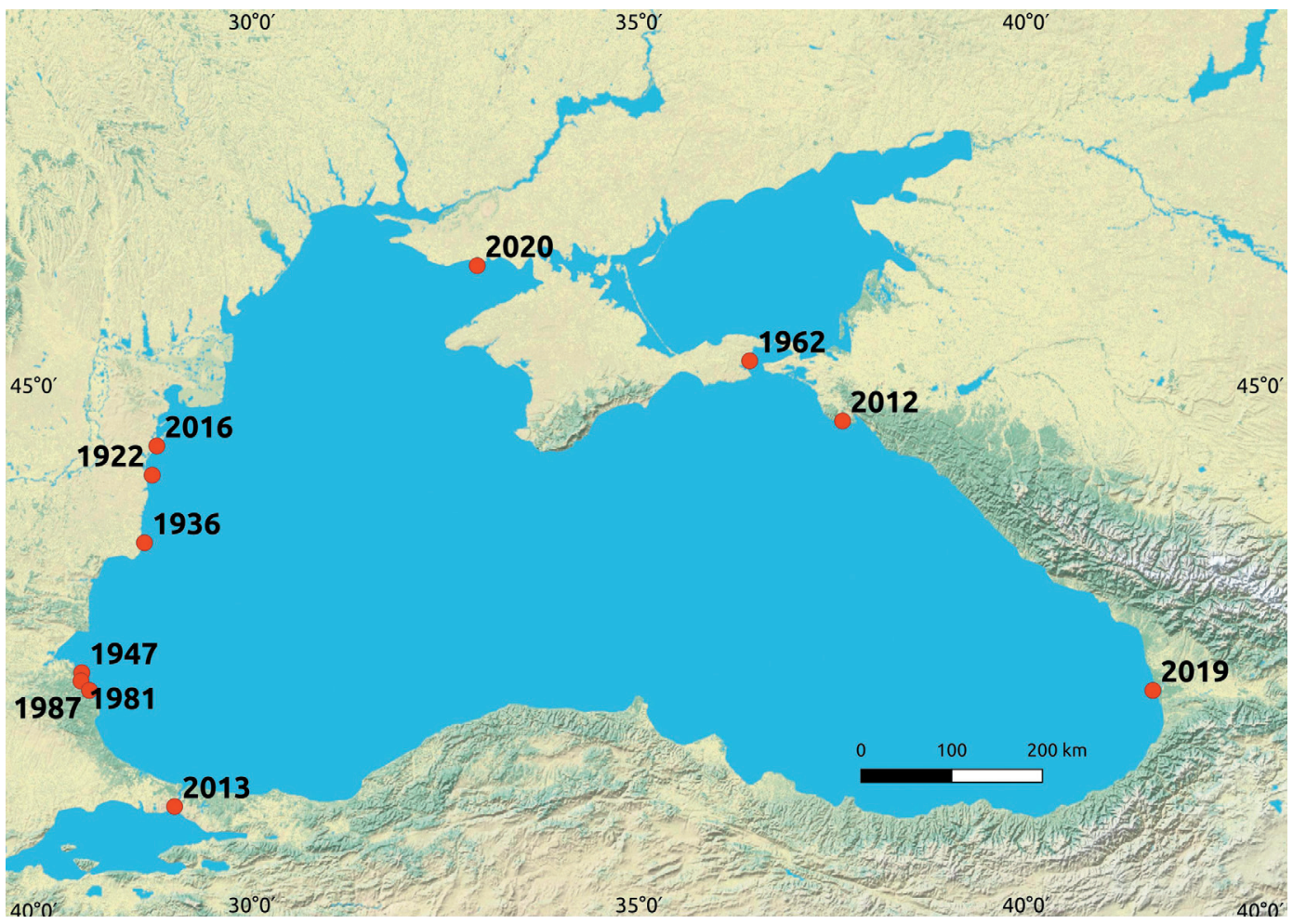

Fig. 1. Records of the loggerhead sea turtle in the Black Sea. 


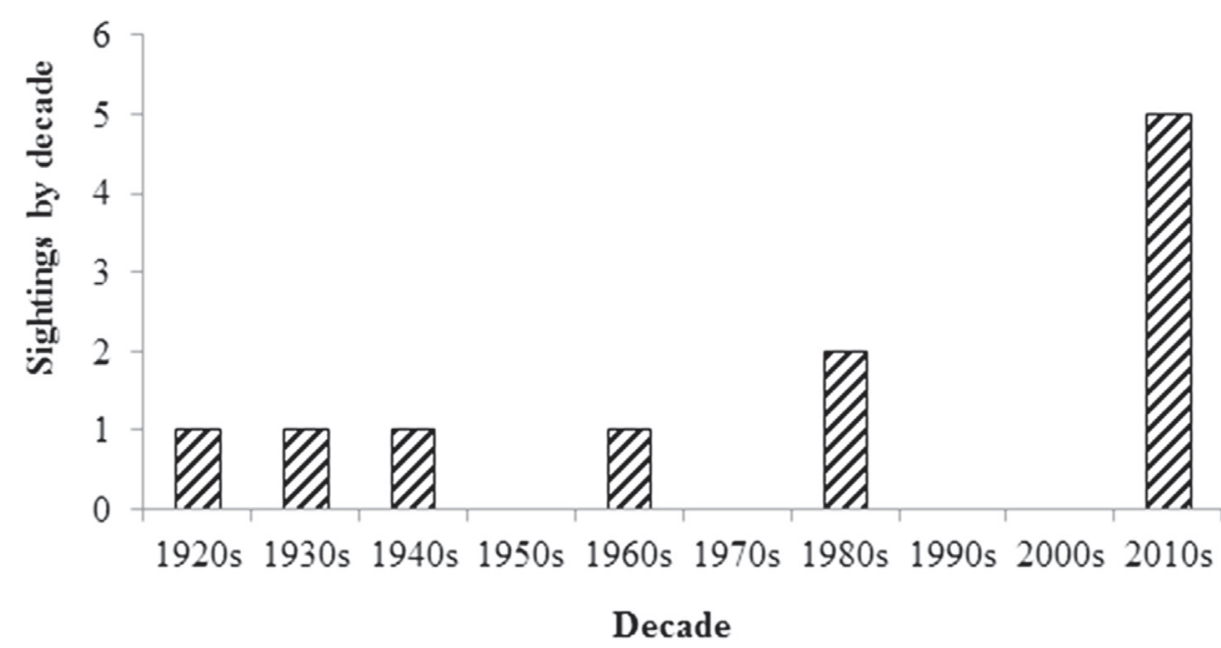

Fig. 2. Frequency of records of the loggerhead sea turtle in the Black Sea by decade.

(CL). The body mass was $37 \mathrm{~kg}$, as reported by a local fishermen. Thus, its curved carapace length (CCL) is estimated at between 66 and $77 \mathrm{~cm}$ based on allometric regressions (Casale et al., 2017). The size category matched the subadult age or age of attaining of the sexual maturity. The tail was short. The plastron-cloaca distance was less than $10 \mathrm{~cm}$, and the plastron-tail distance was ca. $15 \mathrm{~cm}$ : these features and measurements at the specimen's CCL category indicated it was a female (Casale et al., 2005).

The observed specimen did not have any injures and scars but it was easy recognizable between two observations because of the presence of three large barnacles on the right anterior part of its carapace and at least four more on the left part of its plastron.

From the timeline perspective, during the latest decade loggerhead observations became more frequent in the Black Sea than over all the previous observation period: five cases were encountered in 2012-2020 (2012, Novorossiysk; 2013, Istanbul; 2016, Vama Veche; 2019, Poti, and 2020; Dzharylhach), while only six events were reported during the 20th century (1922, Constanta; 1936, Shabla Cape; 1947, Maslen Cape; 1963, Eltigen; 1981, Kiten, and 1987, Ahtopol) (figs. 1, 2; table 1). The time intervals between the sightings became significantly shorter after 2012 (Chi-square test, Kolmogorov-Smirnov test, $\mathrm{p}<0.05$ ). The only record of a live sea turtle in spring in recent years (Anonymous, 2019) may indicate on possible successful overwintering in the Black Sea and the possibility for sea turtles to establish a permanent population there.

\section{Discussion}

The body size of the specimen, as compared to records from the Mediterranean Sea, corresponds to the age between 15 and 25 years that is a subadult age close to the sexual maturity (Casale et al., 2005, 2009, 2011). This is the age category, for which pelagic stage with migrations and omnivorous way of life, including jellyfish feeding, is possible (Casale et al., 2007).

The closest nesting sites of the loggerhead are situated in the East Mediterranean, Chania and Rethymno on the Crete and Dalyan in the south-east Aegean Sea, at least 1,500 km from the Dzharylhach Bay (Casale et al., 2018). However, individual migrations over long distances are known from other Mediterranean areas, e.g., between the Central and Western Mediterranean (Casale et al., 2007). Recent climate changes already affected the range of the loggerhead in the Mediterranean: while the southern habitats become less suitable, new nesting sites appear to the west and north, beyond the historical range (Maffucci et 
Table 1. Records of the Loggerhead C. caretta in the Black Sea in the 20th and 21st centuries

\begin{tabular}{|c|c|c|c|c|c|}
\hline Locality & $\mathrm{N}$ & $\mathrm{E}$ & Date & Reference & \\
\hline $\begin{array}{l}\text { North from the Constanta, } \\
\text { Romania }\end{array}$ & 44.17 & 28.71 & 1922 & $\begin{array}{l}\text { Lepsi, 1925, cited after } \\
\text { Nankinov, } 1998\end{array}$ & Found dead \\
\hline Cape Shabla, Bulgaria & 43.54 & 28.61 & 29.03.1936 & $\begin{array}{l}\text { Popovici, 1936, cited } \\
\text { after Nankinov, } 1998\end{array}$ & Stranded \\
\hline Maslen Nos, Bulgaria & 42.31 & 27.8 & $\begin{array}{l}\text { End of } \\
\text { November } \\
1947\end{array}$ & $\begin{array}{l}\text { Valkanov, 1949, cited } \\
\text { after Nankinov, } 1998\end{array}$ & $\begin{array}{l}\text { Bycaught alive, } \\
\text { young }\end{array}$ \\
\hline $\begin{array}{l}\text { Heroivka (Eltigen), Kerch, } \\
\text { Crimea, Ukraine }\end{array}$ & 45.22 & 36.43 & $\begin{array}{l}\text { September } \\
1962\end{array}$ & Taranenko, 1963 & $\begin{array}{l}\text { Bycaught alive, } \\
35 \mathrm{~kg}\end{array}$ \\
\hline $\begin{array}{l}\text { Between Kiten and } \\
\text { Lozenec, Bulgaria }\end{array}$ & 42.23 & 27.79 & August 1981 & $\begin{array}{l}\text { P. Petkov, cited after } \\
\text { Nankinov, } 1998\end{array}$ & Spotted in the sea \\
\hline $\begin{array}{l}\text { Between Ahtopol and } \\
\text { Michurin, Bulgaria }\end{array}$ & 42.14 & 27.9 & August 1987 & Nankinov, 1998 & $\begin{array}{l}\text { ca. } 1-2 \mathrm{~km} \text { off the } \\
\text { shore, three speci- } \\
\text { mens }\end{array}$ \\
\hline $\begin{array}{l}\text { Yuzhnaya Ozerejka, } \\
\text { Novorossiysk, Russian } \\
\text { Federation }\end{array}$ & 44.67 & 37.63 & 14.04 .2012 & Pestov \& Kletnoy, 2012 & $\begin{array}{l}\text { Dead specimen, } \\
\text { stranded }\end{array}$ \\
\hline $\begin{array}{l}\text { Istanbul Strait Kandilli, } \\
\text { Stambul, Turkey }\end{array}$ & 41.02 & 29 & 29.07.2013 & Tonay \& Oruc, 2016 & \\
\hline Vadu, Romania & 44.44 & 28.77 & 6.09 .2016 & Tonay \& Oruc, 2016 & On the beach \\
\hline Poti, Georgia & 42.14 & 41.64 & March, 2019 & Anonymous. 2019. & Live specimen \\
\hline Dzharylhach, Ukraine & 46.08 & 32.91 & $\begin{array}{l}\text { September } \\
2020\end{array}$ & This publication & Bycaught alive \\
\hline
\end{tabular}

al., 2016). Therefore, expansion of the loggerhead towards the Black Sea well concurs with the overall trend of this pan-Mediterranean expansion. Meanwhile, some of these habitats may be suitable for the loggerhead only in summer because of non-optimal winter temperatures which limit its expansion (Maffucci et al., 2016). This is especially true for the loggerhead in the Black Sea: the temperature of $+5-6^{\circ} \mathrm{C}$ is lethal for this species, and $+10^{\circ} \mathrm{C}$ inhibits its locomotory activity (Schwartz, 1978). Moreover, the threshold for hibernation is considered to be under $+15^{\circ} \mathrm{C}$; however, the Mediterranean loggerheads were observed to be active at temperatures above $+12{ }^{\circ} \mathrm{C}$ (Hochscheid et al., 2007). At present, only the south-eastern Black Sea has the winter conditions of the sea surface close to normal for this species (Kazmin et al., 2010) and simulations does not show a clear trend to increase of water temperatures in long-term run (Miladinova et al., 2017), although the positive anomaly of average annual surface sea temperature has been detected since 2007 which is the longest period for 150 years (Annual.., 2018). In this case, suitable only in summer months and lacking reproduction sites, Black Sea could be considered as the ecological trap for migrant sea turtles from the Mediterranean. However, ongoing climate changes, with some sea surface warming during the latest 25 years, and their predictions for future decades (Sakalli \& Başusta, 2018) show that the Black Sea may eventually become a suitable year-round habitat for the loggerhead. An increasing number of sightings of the loggerhead turtles in the Black Sea, at least five events for the past ten years, compared to six events observed during the previous century, shows a clear trend of expansion of the species seasonal range into this region.

Range expansion of the Mediterranean biota into the Black Sea ('Mediterranization') is a long-lasting and well known phenomenon which was detected across numerous taxonomic groups (Pusanow, 1967; Shiganova \& Öztürk, 2010). Among them, at least sixteen Mediterranean fish species were first recorded in the Black Sea for the last 30 years, and at least ten Mediterranean fish species were first recorded near the Ukrainian coast (Shiganova \& Öztürk, 2010; Kvach \& Kutsokon, 2017). There are evidences for recent strengthening this trend for fishes during the latest decade and, interestingly, gradual west to east ex- 
pansion was detected for several species (Kvach \& Kutsokon, 2017). Now it is shown that marine amniotes, such as turtles, follow this trend.

\section{Conclusions}

The loggerhead sea turtles of the east Mediterranean origin are increasingly seen in the Marmara and the Black Seas during the latest decade. This is an evidence for potential northward expansion of the species range, at least partly due to climate changes, which are increasingly suitable for the loggerhead. This finding could be viewed within ongoing invasion of the Mediterranean biota to the Black Sea region driven by climate change and salinity rise. Gradual steady warming of the water surface, which is observed in the Black Sea during the latest decades, is beneficial for this species, and a number of its findings is expected to grow.

Authors thank the Skadovsk fishermen community for providing data on the record and two anonymous reviewers for comments to the manuscript.

\section{References}

Annual average sea surface temperature anomaly. Provided by Copernicus Marine Environment Monitoring Service. 2018. https://www.eea.europa.eu/data-and-maps/daviz/annual-average-sea-surface-temperature-6

Anonymous. 2019. Rare giant tortoise found in Georgia's seaside town of Poti. https://agenda.ge/en/ news/2019/817

Casale, P., Freggi, D., Basso, R., Argano, R. 2005. Size at male maturity, sexing methods and adult sex ratio in loggerhead turtles (Caretta caretta) from Italian waters investigated through tail measurements. The Herpetological Journal, 15 (3), 145-148.

Casale, P., Freggi, D., Basso, R., Vallini, C., Argano, R. 2007. A model of area fidelity, nomadism, and distribution patterns of loggerhead sea turtles (Caretta caretta) in the Mediterranean Sea. Marine Biology, 152 (5), 1039-1049.

Casale, P., Mazaris, A. D., Freggi, D., Vallini, C., Argano, R. 2009. Growth rates and age at adult size of loggerhead sea turtles (Caretta caretta) in the Mediterranean Sea, estimated through capture-mark-recapture records. Scientia Marina, 73 (3), 589-595.

Casale, P., Mazaris, A. D., Freggi, D. 2011. Estimation of age at maturity of loggerhead sea turtles Caretta caretta in the Mediterranean using length-frequency data. Endangered Species Research, 13 (2), 123-129.

Casale, P., Freggi, D., Rigoli, A., Ciccocioppo, A., Luschi, P. 2017. Geometric morphometrics, scute patterns and biometrics of loggerhead turtles (Caretta caretta) in the central Mediterranean. Amphibia-Reptilia, $38,145-156$.

Casale, P., Broderick, A. C., Camiñas, J. A., Cardona, L., Carreras, C., Demetropoulos, A., Fuller, W. J., Godley, B. J., Hochscheid, S., Kaska, Y., Lazar, B., Margaritoulis, D., Panagopoulou, A., Rees, A. F., Tomás, J., Türkozan, O. 2018. Mediterranean sea turtles: current knowledge and priorities for conservation and research. Endang. Species Res. 36, 229-267. https://doi.org/10.3354/esr00901

Georgiev, V. 1979. Turtles in the Black Sea. Kooperativno selo, 22, 01.02 .1979 [In Bulgarian].

Hochscheid, S., Bentivegna, F., Bradai, M. N., Hays, G. C. 2007. Overwintering behaviour in sea turtles: dormancy is optional. Marine Ecology Progress Series, 340, 287-298.

Kazmin, A. S., Zatsepin, A. G., Kontoyiannis, H. 2010. Comparative analysis of the long-term variability of winter surface temperature in the Black and Aegean Seas during 1982-2004 associated with the large-scale atmospheric forcing. International journal of climatology, 30 (9), 1349-1359.

Kvach, Y., Kutsokon, Y. 2017. The non-indigenous fishes in the fauna of Ukraine: a potentia ad actum. BioInvasions Record, 6 (3), 263-279.

Maffucci, F., Corrado, R., Palatella, L., Borra, M., Marullo, S., Hochscheid, S., Lacorata, G., Iudicone, D. 2016. Seasonal heterogeneity of ocean warming: a mortality sink for ectotherm colonizers. Scientific reports, 6 (1), 23983.

Miladinova, S., Stips, A., Garcia-Gorriz, E., Macias Moy, D. 2017. Black Sea thermohaline properties: Longterm trends and variations. Journal of Geophysical Research Oceans, 122 (7), 5624-5644.

Musick, J. A. 2003. Sea Turtles. In: Carpenter, K. E., ed. The living marine resources of the Western Central Atlantic. Vol. 3: Bony fishes part 2 (Opistognathidae to Molidae), sea turtles and marine mammals. FAO Species Identification Guide for Fishery Purposes and American Society of Ichthyologists and Herpetologists Special Publication No. 5. FAO, Rome, 1426-1468.

Nankinov, D. M. 1998. Occurrence of marine turtles (Caretta caretta and Chelonia mydas) along the west Black Sea coast. Glasnik Prirodnjačkog Muzeja u Belgradu B, 49-50, 7-14. 
Özdilek, Ş. Y., Sönmez, B., Sert, M. 2018. Stranded sea turtle records between 2010 and 2017 in northern Aegean and Sea of Marmara. Regional Studies in Marine Science, 24, 17-22.

Pestov, M. V., Kletnoy, M. V. 2012. Finding of the sea turtle Caretta caretta at the Russian coast of the Black Sea. Sovremennaya Herpetologia, 12 (3-4), 158-159.

Pusanow, I., 1967. Über die sukzessiven Stadien der Mediterranisation des Schwarzen Meeres. Internationale Revue der gesamten Hydrobiologie und Hydrographie, 52 (2), 219-236.

Sakalli, A., Başusta, N. 2018. Sea surface temperature change in the Black Sea under climate change: A simulation of the sea surface temperature up to 2100. International Journal of Climatology, 38 (13), 4687-4698.

Schwartz, F. J. 1978. Behavioral and tolerance re sponses to cold water temperatures by three species of sea turtles (Reptilia, Cheloniidae) in North Carolina. In: Henderson, G. E., ed. Florida and Interregional Conference on Sea Turtles. Florida Marine Research Publications, 16-18.

Shiganova, T. A., Öztürk, B. 2010. Trend on increasing Mediterranean species arrival into the Black Sea. In: Briand, F., ed. CIESM Workshop Monographs, No 39. Climate Forcing and Its Impact on the Black Sea Biota. CIESM, Monaco, 75-93.

Taranenko, N. F., 1963. The green turtle in the Kerch Strait. Priroda, 9, 115-116 [In Russian].

Tonay, A. M., Oruç, A. 2016. Sea turtle records and conservation in the sea of Marmara. In: Özsoy, E., Çağatay, M. N., Balkıs, N., Balkıs, N., Öztürk, B., eds. The Sea of Marmara; Marine Biodiversity, Fisheries, Conservation and Governance. Turkish Marine Research Foundation (TUDAV), Publication No: 42. Istanbul, 843-848.

Received 28 December 2020

Acceped 3 March 2021 